\title{
Efek Probiotik Terhadap Interleukin-6 Serum dan Skor Depresi pada Pasien Luka Bakar
}

\section{Probiotic Effects of Interleukin-6 Serum Level and Depression Score on Burn Patients}

Oleh : Nur Aida ${ }^{1}$, Azimatul karimah ${ }^{2}$, Iswinarno Doso Saputro ${ }^{3}$

\footnotetext{
${ }^{1}$ Dokter umum, peserta PPDS I Ilmu Kedokteran Jiwa Departemen/ SMF Ilmu Kedokteran Jiwa FK Universitas Airlangga/RSU Dr. Soetomo Surabaya, alamat korespondensi: Jl. Jatisari Besar III/34, Pepelegi, Waru, Sidoarjo, email: nuraidaa187@gmail.com. No. HP: 082131119739

${ }^{2}$ Psikiater Konsultan, Staf Pengajar pada Departemen/ SMF Ilmu Kedokteran Jiwa FK Universitas Airlangga/ RSU Dr. Soetomo Surabaya ${ }^{3}$ Doktor, dokter Spesialis Bedah Plastik (Konsultan), Staf Pengajar pada Departemen /SMF Bedah Plastik FK Universitas Airlangga/RSUD Dr. Soetomo Surabaya
} 


\begin{abstract}
ABSTRAK
Latar Belakang: Luka bakarmerupakan respon lokal suatu jaringan dengan atau tanpa respon sistemik terhadap suatu perpindahan energi dari sumber fisik atau kimia. Perawatan luka bakar memerlukan waktu yang lama. Dampak pada individu karena luka bakar dirasakan sejak awal cedera dan meluas di seluruh kehidupan seseorang. Pada luka bakar tejadi pelepasan mediator inflamasi khususnya interleukin-6 dan terganggunya berbagai faal tubuh, salah satunya homeostasis mikrobiota usus. Komorbiditas psikiatrik yang terjadi berkisar 45,5\%, dimana depresi yang hadir akan memperberat kondisi pasien. Probiotik dapat menurunkan kadar interleukin-6 dan mencegah gejala depresi secara langsung maupun tidak langsung. Studi ini untuk menilai efek suplementasi probiotik pada gejala depresi, parameter menggunakan biomarker IL-6 serum.Tujuan: Membuktikan efek probiotik terhadap interleukin-6 serum dan skor depresi pada pasien luka bakar. Metode: Desain penelitian adalah non randomized control trial. Sampel diambil dengan consequtive sampling. Pemberian probiotik pada hari ke 4 sampai hari ke 19 perawatan, kadar interleukin-6 serum diukur pada hari ke-4 (sebelum pemberian probiotik) dan hari ke 19 (setelah pemberian probiotik) dengan ELISA. Kelompok kontrol tidak menerima probiotik. Kriteria depresi diukur dengan Hamilton Depression Rating Scale (HDRS). Kedua alat ukur tersebut telah melalui uji validitas dan reliabilitasnya dari penelitian sebelumnya dan HDRS telah diadaptasi ke dalam bahasa Indonesia. Analisis data menggunakan uji komparatif. Hasil: Hasil uji statistik menunjukkan tidak ada perbedaan yang bermakna antara kelompok perlakuan dan kontrol.Kesimpulan: Pemberian probiotik tidak berpengaruh terhadap kadar interleukin-6 serum dan derajat depresi dibandingkan kontrol
\end{abstract}

Kata kunci : luka bakar, probiotik, interleukin-6, depresi

\title{
ABSTRACT
}

Background: Burns are a local response of tissues with or without a systemic response to an energy transfer from a physical or chemical source. Burn treatment takes a long time. The individual impact of burns is felt from the beginning of injury and extends to one's life. In burns occurs the release of inflammatory mediators, especially interleukin-6 and disruption of various body physiology, one of them homeostasis intestinal microbiota. The psychiatric comorbidities that occur in the range $45.5 \%$, where the present depression will aggravate the patient's condition. Probiotics can reduce levels of interleukin-6 and prevent symptoms of depression directly or indirectly. This study to assess the effect of probiotic supplementation on depressive symptoms, parameters using serum IL-6 biomarkers. Objective: To prove the effect of probiotics on serum interleukin-6 and depression score in burn patients. Method: The study design was non randomized control trial. Samples were taken with consequtive sampling. Administering probiotics on day 4 to day 19 of care, serum interleukin-6 levels were measured on day 4 (before probiotic) and day 19 (after probiotic) with ELISA. The control group did not receive probiotics. Depression criteria were measured by the Hamilton Depression Rating Scale (HDRS). Both of these measuring instruments have passed the validity and reliability test from previous research and HDRS has been adapted into Indonesian. Data analysis using comparative test. Results: The results of statistical tests showed no significant differences between treatment and control groups. Conclusion: Provision of probiotics did not affect serum interleukin-6 levels and depression levels compared with control

Keywords: burns, probiotics, interleukin-6, depression 


\section{PENDAHULUAN}

Luka bakar melibatkan respon suatu jaringan terhadap perpindahan energi dari sumber fisik (mekanik, panas, listrik, radiasi atau kimia), lokal maupun sistemik. World Health Organization (WHO) melaporkan angka mortalitas 300.000 pertahun untuk seluruh dunia (Mitsunaga et al., 2012; Pereira et al., 2012). Data Kesehatan Dasar Depkes RI 2007 menyatakan bahwa prevalensi tertinggi luka bakar di Indonesia di provinsi Nangroe Aceh Darussalam dan Kepulauan Riau sebesar 3,8\%. Profil luka bakar Unit Perawatan Luka Bakar RSUD Dr. Soetomo Surabaya tahun 2007-2011 didapatkan angka mortalitas 14,1\% (Saputroet al., 2012). Komorbiditas psikiatrik berkisar 45,5\%, salah satunya adalah depresi. Prevalensi depresi ringan sampai sedang $23 \%$ sampai $26 \%$, depresi berat $4 \%$ sampai $10 \%$. Penanganan luka bakar sebaiknya dikelola oleh tim trauma termasuk dari bidang psikiatri sehingga depresi dapat ditangani dengan tepat (Alvi et al, 2009).

Pada luka bakar tejadi pelepasan mediator inflamasi khususnya interleukin-6 dan terganggunya homeostasis mikrobiota usus. Mikrobiota mempengaruhi perkembangan saraf, kognisi dan perilaku melalui jalur gut brain axis. Beberapa penelitian menunjukkan pemberian probiotik mampu mengendalikan interleukin-6 dan memperbaiki homeostasis mikrobiota usus saat terjadinya inflamasi. Probiotik didefinisikan sebagai makanan atau obatobatan yang mengandung mikroba hidup yang memiliki efek menguntungkan pada host (Gun et al., 2005). Mekanisme kerja probiotik meliputi kompetisi reseptor, efek sekresi mukus, imunomodulasi jaringan limfoid yang berhubungan dengan usus, peningkatan imunosupresi dan menurunkan mediator proinflamasi (Wadher et al, 2010). Probiotik dapat digunakan untuk mengurangi stres, dan beberapa kondisi patologis mental lainnya termasuk depresi (Vyas \& Ranganathan, 2012). Tujuan umum penelitian ini adalah membuktikan bahwa pemberian probiotik menurunkan kadar interleukin-6 serum dan derajat depresi pasien luka bakar.

\section{METODOLOGI}

Penelitian ini merupakan studi eksperimental dengan menggunakan Non Randomized Clinical Trial. Populasi penelitian adalah pasien luka bakar yang dirawat di Ruang Unit Perawatan Luka Bakar RSUD dr. Soetomo, dalam kurun waktu tertentu (November 2016-Maret 2017). Pengambilan sampel dilakukan secara consecutive sampling dengan kriteria inklusi adalah pasien luka bakar dengan luas luka bakar sedang-berat berdasarkan kriteria American Burn Association yang terjadi $<24$ jam sebelum dibawa ke rumah sakit, usia 18-60 tahun, intake secara oral/enteral, menandatangani informed consent, SRSS (Social Readjusment Rating Scale) $<300$ sebelum luka bakar. Kriteria eksklusi: Wanita hamil dan menyusui, memiliki riwayat penyakit autoimun, sudah mengkonsumsi probiotik sebelumnya, memiliki riwayat skizoafektif dan gangguan bipolar, menderita retardasi mental. Kriteria Drop Out: Pasien yang meninggal saat penelitian, pasien yang mengundurkan diri dari penelitian. Subyek penelitian terdiri dari kelompok perlakuan dan kelompok kontrol. Pemberian probiotik pada hari ke 4 sampai hari ke 19 pada kelompok perlakuan, kelompok kontrol tanpa pemberian probiotik. 
Kadar interleukin-6 serum diukur hari ke-4 dan hari ke 19 dengan teknik ELISA dan skor depresi diukur dengan Hamilton Depression Rating Scale (HDRS).

\section{HASIL}

Subyek penelitian yang memenuhi kriteria inklusi 21 orang dan drop out 1 orang. Namun yang menyelesaikan penelitian 20 pasien, 13 pasien kelompok perlakuan dan 7 pasien kelompok kontrol. Jumlah subyek penelitian berbeda karena terbatasnya waktu dan jumlah pasien yang memenuhi kriteria inklusi.

Tabel 1. Data Karakteristik Subyek Penelitian

\begin{tabular}{|c|c|c|c|c|c|c|}
\hline \multirow{2}{*}{ Kelompok } & \multirow{2}{*}{ Kategori } & \multicolumn{2}{|c|}{ Perlakuan } & \multicolumn{2}{|c|}{ Kontrol } & \multirow{2}{*}{$\mathrm{P}$} \\
\hline & & $\mathrm{N}$ & $\%$ & $\mathrm{~N}$ & $\%$ & \\
\hline \multirow{2}{*}{$\begin{array}{c}\text { Jenis } \\
\text { Kelamin }\end{array}$} & Laki-Laki & 9 & $69.20 \%$ & 3 & $42.90 \%$ & \multirow{2}{*}{0.356} \\
\hline & Perempuan & 4 & $30.80 \%$ & 4 & $57.10 \%$ & \\
\hline \multirow{5}{*}{ Usia } & 20-29th & 4 & $30.80 \%$ & 2 & $28.60 \%$ & \multirow{5}{*}{0.529} \\
\hline & 30-39th & 3 & $23.10 \%$ & 1 & $14.30 \%$ & \\
\hline & 40-49th & 1 & $7.70 \%$ & 0 & $0 \%$ & \\
\hline & 50-59th* & 5 & $38.50 \%$ & 3 & $42.90 \%$ & \\
\hline & 60-69th & 0 & $0 \%$ & 1 & $14.30 \%$ & \\
\hline \multirow{4}{*}{ Pendidikan } & $\mathrm{SD}$ & 3 & $23.10 \%$ & 0 & $0 \%$ & \multirow{4}{*}{0.521} \\
\hline & SMP & 0 & $0 \%$ & 0 & $0 \%$ & \\
\hline & SMA* & 10 & $76.90 \%$ & 7 & $100 \%$ & \\
\hline & S1 & 0 & $0 \%$ & 0 & $0 \%$ & \\
\hline \multirow{2}{*}{ Pekerjaan } & Bekerja & 3 & $23.10 \%$ & 1 & $14.30 \%$ & \multirow{2}{*}{1.000} \\
\hline & Tidak Bekerja* & 10 & $76.90 \%$ & 6 & $85.70 \%$ & \\
\hline \multirow{2}{*}{ Biaya } & BPJS & 12 & $92.30 \%$ & 3 & $42.90 \%$ & \multirow{2}{*}{$\mathbf{0 , 0 3 1}$} \\
\hline & Mandiri & 1 & $7.70 \%$ & 4 & $57.10 \%$ & \\
\hline \multirow{2}{*}{ Penghasilan } & $<1 \mathrm{Jt}$ & 0 & $0 \%$ & 2 & $28.60 \%$ & \multirow{2}{*}{0,111} \\
\hline & $\geq 1 \mathrm{Jt} *$ & 13 & $100 \%$ & 5 & $71.40 \%$ & \\
\hline \multirow{3}{*}{$\begin{array}{l}\text { Luas Luka } \\
\text { Bakar }\end{array}$} & $10-20 \%$ & 5 & $38.50 \%$ & 2 & $28.60 \%$ & \multirow{3}{*}{0.712} \\
\hline & $21-40 \%$ & 3 & $23.10 \%$ & 4 & $57.10 \%$ & \\
\hline & $41-70 \%$ & 5 & $38.50 \%$ & 1 & $14.30 \%$ & \\
\hline
\end{tabular}

Ket : $\quad$ - Tanda * menunjukkan jumlah subyek penelitian terbanyak

- Tingkat kemaknaan bila $(\mathrm{p}<0,05)$

Tabel di atas menunjukkan hanya faktor pembiayaan yang berbeda secara bermakna dengan $\mathrm{p}=$ 0,031(p<0,05), sedangkan faktor yang lainnya (jenis kelamin, usia, pendidikan, pekerjaan, penghasilan, luas luka bakar) tidak menunjukkan perbedaan bermakna dengan ( $p>0,05)$.

Tabel 2. Komparasi Kadar IL-6 Serum dan Skor HDRS 


\begin{tabular}{|c|c|c|c|c|c|c|c|c|c|}
\hline \multirow[b]{2}{*}{ Kelompok } & \multicolumn{4}{|c|}{ Perlakuan } & \multicolumn{4}{|c|}{ Kontrol } & \multirow{2}{*}{$\begin{array}{c}\mathrm{p} \\
(\Delta \text { perlakuan } \\
\text { dibandingkan } \\
\Delta \text { kontrol })\end{array}$} \\
\hline & Sebelum & Sesudah & $\mathrm{p}$ & $\Delta$ & Sebelum & Sesudah & $\mathrm{p}$ & $\Delta$ & \\
\hline Kadar IL-6 & $\begin{array}{l}137.68 \pm \\
146.22\end{array}$ & $\begin{array}{l}130.89 \pm \\
150.45\end{array}$ & 0.90 & $\begin{array}{l}-6.79 \pm \\
189.90\end{array}$ & $\begin{array}{l}136.33 \pm \\
91.35\end{array}$ & $\begin{array}{l}134.59 \pm \\
82.74\end{array}$ & 0.95 & $\begin{array}{l}-1.74 \pm \\
71.41\end{array}$ & 0.95 \\
\hline Skor HDRS & $\begin{array}{l}16.46 \pm \\
7.13\end{array}$ & $\begin{array}{l}16.31 \pm \\
8.80\end{array}$ & 0.96 & $\begin{array}{l}-0.15 \pm \\
11.50\end{array}$ & $\begin{array}{l}10.43 \pm \\
5.91\end{array}$ & $\begin{array}{l}12.86 \pm \\
9.35\end{array}$ & 0.53 & $\begin{array}{l}2.43 \pm \\
9.68\end{array}$ & 0.62 \\
\hline
\end{tabular}

Ket : Tingkat kemaknaan bila $(\mathrm{p}<0,05)$

Tabel 2 menunjukkan hasil uji statistik komparasi sebelum dan sesudah perlakuan (uji paired $t$ test) berdasarkan data sampel berskala numerik yang berdistribusi normal. Nilai $(\mathrm{p}>0,05)$ pada variabel kadar interleukin-6 dan variabel skor HDRS sebelum dan sesudah perlakuan menunjukkan tidak ada perbedaan kadar interleukin-6 dan derajat depresi sebelum dan sesudah perlakuan baik pada kelompok perlakuan maupun kelompok kontrol. Pada kelompok perlakuan rerata skor HDRS lebih tinggi dibandingkan kelompok kontrol sebelum maupun sesudah perlakuan meskipun hal ini tidak menimbulkan perbedaan yang bermakna, kemungkinan disebabkan metode penelitian tidak double blind yang menimbulkan bias saaat melakukan skoring HDRS, dan faktor pengambil skor HDRS yang tidak selalu dilakukan oleh orang yang sama karena terkendala masalah teknis.

Uji independent $t$ test pada variabel selisih kadar interleukin-6 dan selisih skor HDRS pada kelompok perlakuan dan kelompok kontrol diperoleh nilai $(\mathrm{p}>0,05)$ yang menunjukkan tidak ada perbedaan bermakna pada perubahan kadar interleukin-6 dan perubahan derajat depresi baik pada kelompok perlakuan maupun kelompok kontrol.

Tabel 3. Hubungan Kadar IL-6 Serum dan Skor HDRS

\begin{tabular}{|c|c|c|c|c|c|c|c|c|c|c|c|c|}
\hline \multirow{2}{*}{ Kelompok } & \multicolumn{3}{|c|}{ IL-6 } & \multicolumn{3}{|c|}{ Skor HDRS } & \multicolumn{3}{|c|}{ r (IL-6 dan HDRS) } & \multicolumn{3}{|c|}{$\mathrm{p}$ (IL-6 dan HDRS) } \\
\hline & Sebelum & Sesudah & $\Delta$ & Sebelum & Sesudah & $\Delta$ & Sebelum & Sesudah & $\Delta$ & Sebelum & Sesudah & $\Delta$ \\
\hline Perlakuan & $\begin{array}{c}137.68 \\
\pm \\
146.22\end{array}$ & $\begin{array}{c}130.87 \\
\pm \\
150.45\end{array}$ & $\begin{array}{c}6.79 \\
\pm \\
189.90\end{array}$ & $\begin{array}{c}16.46 \\
\pm \\
7.13\end{array}$ & $\begin{array}{c}16.31 \\
\pm \\
8.80\end{array}$ & $\begin{array}{c}0.15 \\
\pm \\
11.50\end{array}$ & -0.87 & 0.17 & $-0,17$ & 0.78 & 0.58 & 0,58 \\
\hline Kontrol & $\begin{array}{c}136.3 \\
\pm \\
91.35\end{array}$ & $\begin{array}{c}134.60 \\
\pm \\
82.74\end{array}$ & $\begin{array}{c}1.7 \\
\pm \\
71.41\end{array}$ & $\begin{array}{c}10.43 \\
\pm \\
5.91\end{array}$ & $\begin{array}{c}12.86 \\
\pm \\
9.34\end{array}$ & $\begin{array}{c}2.43 \\
\pm \\
9.68\end{array}$ & 0.82 & 0.55 & 0,46 & 0.02 & 0.2 & 0,30 \\
\hline
\end{tabular}

Ket : Tingkat kemaknaan bila $(\mathrm{p}<0,05)$

Nilai $(p<0,05)$ pada kelompok kontrol sebelum perlakuan menunjukkan kadar interleukin-6 mempunyai hubungan bermakna terhadap derajat depresi, yang artinya semakin tinggi kadar interleukin-6 semakin tinggi derajat depresi pada hari ke-4 setelah luka bakar. Tabel 3 juga menunjukkan tidak ada hubungan yang bermakna perubahan kadar IL-6 dan perubahan derajat depresi pada kelompok perlakuan dibandingkan kontrol, nilai $(p>0,05)$. 


\section{DISKUSI}

Tabel 1 menunjukkan faktor biaya memiliki perbedaan yang bermakna antara kelompok perlakuan dan kelompok kontrol yang mengindikasikan bahwa faktor biaya memegang peranan penting dalam luka bakar. Hal ini sesuai dengan pernyataan Pavoni et al (2010) bahwa perawatan luka bakar memerlukan biaya yang besar untuk penatalaksanannya meliputi pemeriksaan (klinis dan laboratorium), obat-obatan maupun tindakan yang akan dilakukan. Pemberian probiotik berpengaruh terhadap kenaikan kadar interleukin-6 tampak pada tabel 2. Lama waktu pemberian probiotik pada sebagian besar penelitian dalam fase akut (kurang dari 3 minggu) sedangkan fase subakut (3-8 minggu). Pemberian probiotik pada penelitian ini 2 minggu. Hasil penelitian ini sesuai dengan oleh Olguin et al (2010) yang menunjukkan bahwa probiotik tidak menormalkan permeabilitas saluran pencernaan. Namun, percobaan Argenta et al (2016) pada tikus dengan luka bakar menyatakan tidak terdapat kenaikan IL-6 dibanding plasebo pada pemberian probiotik, yang berarti probiotik mampu menghambat kenaikan kadar IL-6 (Tahiret al, 2014).

Hasil penelitian ini mendukung studi Olguin et al (2004) dimana kadar interleukin-6 dengan pemberian probiotik maupun tidak diberikan tidak menunjukkan perbedaan dalam fitur klinis (Tahir et al, 2014). Setelah cedera termal, mukosa usus tidak dapat bertindak sebagai penghalang yang kuat terhadap masuknya bakteri, fungsi imunologi mungkin terganggu setelah penyebaran bakteri patogen ke dalam sirkulasi sistemik (Magnotti \& Deitch, 2005). Kolonisasi mikroba terjadi terutama dari sumber endogen. Infeksi disebabkan oleh hilangnya penghalang epitel, asupan yang kurang karena respon hipermetabolik, dan imunosupresi akibat pelepasan agen imunoreaktif dari luka bakar. Setelah 24-48 jam kejadian luka bakar, terjadi migrasi organisme gram positif selanjutnya migrasi organisme gram negatif yang berasal dari lingkungan rumah sakit. Translokasi mikroorganisme dari saluran pencernaan adalah faktor utama untuk infeksi nosokomial dan kolonisasi luka bakar (Tahir et al, 2014).

Tidak ada perubahan derajat depresi sebelum dan setelah pemberian probiotik selama 14 hari dapat dilihat pada tabel 2. Demikian pula jika dibandingkan dengan kelompok kontrol, probiotik tidak memberikan pengaruh terhadap derajat depresi pada pasien luka bakar (tabel 2). Hal ini tidak sesuai dengan studi eksperimental oleh Messaoudi et al (2011) dimana pemberian Lactobacillus helveticus dan Bifidobacterium longum selama 30 hari menunjukkan penurunan stres psikologis, termasuk depresi (Huang et al, 2016). Namun, uji metaanalisis pada beberapa RCT menunjukkan pemberian probiotik oral bermanfaat untuk pasien dengan depresi dan relawan sehat. Hal ini menunjukkan bahwa probiotik secara signifikan menurunkan skor depresi pada pasien dengan gangguan depresi disamping itu memiliki efek mengurangi risiko depresi pada populasi yang sehat. Studi lain yang dilakukan oleh Akkasheh (2004) menemukan bahwa delapan minggu pemberian probiotik untuk pasien dengan gangguan depresi mayor (MDD) menurunkan skor Beck Depression Inventory (Huang et al, 2016). Benton et al (2006) menemukan dalam intervensi 3 minggu dengan probiotik yang mengandung susu (Lactobacillus casei Shirota) meningkatkan skor suasana hati dibandingkan dengan 
peserta yang menerima plasebo (Messaoudi et al., 2011). Selanjutnya, Rao et al (2009) menunjukkan bahwa pasien dengan sindrom kelelahan kronis, yang sering komorbiditas dengan gangguan kecemasan, melaporkan gejala kecemasan secara signifikan kurang setelah konsumsi dosis harian $L$. casei Shirota selama 2 bulan, dibandingkan dengan kelompok plasebo. Beberapa faktor yang dapat berkontribusi pada penelitian ini, dimana pemberian probiotik tidak berpengaruh dalam menurunkan derajat depresi meliputi hospitalisasi yang dijalani pasien, biaya pengobatan, khawatir tentang kemajuan pengobatan, kelangsungan hidup, morbiditas, kemampuan untuk kembali bekerja dimana faktor tersebut tidak diteliti dalam studi ini (Alvi et al, 2009).

Kenaikan kadar Il-6 yang diikuti penurunan derajat depresi atau sebaliknya pada 4 hari pertama sebelum pemberian probiotik pada kelompok perlakuan (tabel 3). Hal ini sesuai dengan studi pada hewan menunjukkan bahwa bakteri usus dapat mempengaruhi suasana hati dan perilaku dengan cara yang akut. Pada tikus yang diberikan patogen enterik (per oral) lebih gelisah daripada kontrol. Bakteri mencapai sirkulasi darah namun tidak ada peningkatan sitokin pro-inflamasi, menunjukkan peran saraf vagus dalam modulasi perilaku. Para peneliti kemudian menyelidiki jalur neuronal terlibat dalam pengolahan informasi viscerosensory yang menyebabkan respon perilaku. Mereka juga menunjukkan bahwa efek ansiogenik terjadi pada tahap awal infeksi, 7-8 jam paska kolonisasi (Messaoudi, M., 2011).

Pemberian probiotik tidak berpengaruh terhadap hubungan antara kadar interleukin-6 serum dan derajat depresi (tabel 3). Salah satunya disebabkan pada penelitian ini tidak membedakan jenis probiotik, dimana dikatakan probiotik multispesies (yaitu, menggabungkan strain yang berbeda dari generasi tertentu) lebih efektif dibandingkan dengan mono-spesies (Timmerman et al, 2004 dan Chapman et al, 2011). Beberapa probiotik dapat bersaing satu sama lain dalam hal fungsi dan karena itu asumsi bahwa kombinasi dari strain yang berbeda dapat lebih efektif. Di samping itu, terapi antibiotik dalam perawatan luka bakar juga memberikan kontribusi untuk translokasi melalui perubahan flora GIT, sehingga suplementasi probiotik untuk mencegah translokasi bakteri dan melindungi integritas mukosa usus terganggu (Koren et al, 2007). Hal ini berpengaruh juga terhadap komunikasi dua arah sumbu otak-usus yang melalui saraf, endokrin dan jalur imunitas, dimana komunikasi ini melibatkan interaksi dengan mikrobiota usus, yang akan mengaktifkan kekebalan tubuh dan molekul sinyal lain yang berperan dalam mengatur otak dan perilaku berikutnya. Produk bakteri, seperti endotoksin gram negatif, dapat mempengaruhi suasana hati dan fungsi kognitif secara tidak langsung (misalnya, aktivasi kekebalan) dan langsung (misalnya, reseptor Toll-like pada sel glial) (Krabbe et al, 2005, McCusker \& Kelley, 2013). Pemberian probiotik tidak terbukti menghambat proses ini dalam penelitian yang kami lakukan dengan biomarker kadar Il-6 dan skor HDRS.

Sedangkan pada kelompok kontrol, kadar IL-6 serum dan derajat depresi menunjukkan hubungan yang bermakna pada 4 hari pertama dimana perubahan Il-6 dikuti perubahan derajat depresi namun sesudah pengamatan 14 hari tidak menunjukkan hubungan yang bermakna (tabel 3). Dapat dijelaskan 
bahwa proses kolonisasi mikroba di usus menyebabkan perubahan neurokimia di otak dan memberikan sinyal yang mempengaruhi jalur saraf yang terlibat dalam gangguan mood (Messaoudi, 2011). Hasil ini konsisten menunjukkan bahwa IL-6, TNF- $\alpha$, dan IL-1 $\beta$ diduga sebagai biomarker untuk depresi dan respon inflamasi dalam depresi berhubungan dengan stres traumatik (Bob et al, 2010).

Pemberian probiotik tidak berpengaruh terhadap perubahan kadar IL-6 serum dan perubahan derajat depresi pada pasien luka bakar dibanding kontrol (tabel 3). Hal ini tidak sesuai dengan Desbonnet (2010) yang menemukan manfaat potensial dari Bifidobacterium infantis dalam model tikus dimana probiotik dapat menormalisasi respon imun dan mengurangi defisit perilaku. Desbonnet juga menyatakan pemberian probiotik dapat melemahkan pro-inflamasi dan peningkatan triptofan, prekursor serotonergik, Penelitian ini memberikan bukti yang mendukung preposisi bahwa probiotik ini mungkin memiliki sifat antidepresan (Huang et al, 2016). Demikian pula, studi oleh Mohammadi et al (2011), konsumsi yogurt probiotik atau kapsul probiotik multispesies selama 6 minggu memiliki menguntungkan efek pada parameter kesehatan mental pada pekerja petrokimia.

\section{Keterbatasan penelitian}

Peneliti hanya melakukan penilaian fase akut (clinical trial) dimana proses sakit masih terus berlanjut. Pada penelitian ini subyek penelitian tidak diambil secara spesifik dari derajat luas luka bakar, lokasi dan kedalaman luka bakar tertentu. Semua pasien yang mengalami luka bakar sedang dan berat bisa menjadi subyek penelitian asalkan memenuhi kriteria inklusi penelitian.Penelitian ini hanya mengamati perlakuan selama 2 minggu, tidak dilakukan monitoring setelah 3 bulan, 6 bulan, 1 tahun dan seterusnya. Penelitian ini tidak membedakan jenis probiotik, monostrain atau polistrain. Assesment derajat depresi menggunakan kuesioner HDRS, mungkin lebih baik bila menggunakan DASS (Depression Anxiety Stress Scales) yang lebih sesuai untuk mengukur status emosional dari stres, kecemasan dan depresi.Penilaian skor HDRS tidak selalu dilakukan oleh orang yang sama. Penelitian ini tidak mengamati faktor genetik, diet dan obatobatan yang dapat mempengaruhi hasil penelitian.Ukuran sampel yang sederhana, yang akhirnya tidak dapat menilai dampak klinis lain yang bermakna dari probiotik.

\section{KESIMPULAN}

Pemberian probiotik selama 14 hari tidak berpengaruh terhadap perubahan kadar interleukin-6 serum maupun skor depresi serta tidak terdapat korelasi perubahan kadar interleukin-6 serum terhadap skor depresi pada pasien luka bakar sedang-berat dibandingkan kontrol di Ruang Unit Perawatan Luka Bakar di RS dr. Soetomo Surabaya. 


\section{Saran}

Perlunya penelitian lebih lanjut dengan model Double blind, Randomized Control Trial (RCT) untuk membuktikan efek probiotik terhadap kadar interleukin-6 dan derajat depresi dan perlunya memperhatikan protokol pemberian probiotik (dosis, bentuk sediaan, lama pemberian).

\section{DAFTAR PUSTAKA}

Alvi, T., Assad, F., Aurangzeb, Malik, N., 2009. Anxiety and Depression In Burn Patients.J Ayub Med Coll Abbottabad 21(1)

Argenta, A, Satish, L, Gallo, P, et al, 2016. Local Application of Probiotic Bacteria Prophylaxes against Sepsis and Death Resulting from Burn Wound Infection. PLOS ONE | DOI:10.1371/journal.pone.0165294

Benton, D., Williams, C., Brown, A., 2007. Impact of consuming a milk drink containing a probiotic on mood and cognition. Eur J Clin Nutr, 61(3):355-61

Bob, P., Raboch, P., Maes, M., 2010. Depression, traumatic stress and interleukin-6. Journal of Affective Disorders 120: 231-234

Chapman, C.M., Gibson, G.R., Rowland, I., 2011. Health benefits of probiotics: are mixtures more effective than single strains?. Eur. J. Nutr., 50, pp. 1-17 http://dx.doi.org/10.1007/s00394010-0166-Z

Cryan, J.F., O'Mahony, S.M., 2011. The microbiome-gut-brain axis: from bowel to behavior. Neurogastroenterol Motil 23: 187-192.

Dinan, T. \& Cryan, J., 2013. Melancholic microbes: a link between gut microbiota and depression?.Neurogastroenterol Motil25, 713-719

Earley, Z., Akhtar, S., Green, S., et al, 2015. Burn Injury Alters the Intestinal Microbiome and Increases Gut Permeability and Bacterial Translocation, Plos one 1

Frota, P., Zanini, D., 2013. Coping, Personality Traits and Social Support in Severe Burn Survivors. Psychology Vol.4, No.12, 1059-1063

Gun, F, Salman, T, Gurler, N, Olgac, F, 2005. Effect of Probiotic Supplementation on Bacterial Translocation in Thermal Injury. Surg Today 35:760-764

Huang, R., Wang, K., Hu, J., 2016. Effect of Probiotics on Depression: A Systematic Review and Meta-Analysis of Randomized Controlled Trials. Nutrients 8, 483; doi:10.3390/nu8080483

Koren, L., Gurfinkel, R., Glezinger, R., et al, 2007. The effect of Lactobacillus bacteria supplement on sepsis and its complications in patients with acute burns. burns 33,594-598

Krabbe, K., Reichenberg, A.,Yirmiya, R., Smed, A., Pedersen, B., Bruunsgaard, H., 2005.Low-dose endotoxemia and human neuropsychological functions. Brain Behav. Immun., 19, pp. 453460

Magnotti, L., Deitch, E., 2005. Burns, Bacterial Translocation, Gut Barrier Function, and Failure.J 
Burn Care Rehabil ; 26:383-391

McCusker, R.H., Kelley, K.W., 2013. Immune-neural connections: how the immune system's response to infectious agents influences behavior. J. Exp. Biol., 216 (1), pp. 84-98

Messaoudi, M., Violle, N., Bisson, J.,et al, 2011.Beneficial psychological effects of a probiotic formulation (Lactobacillus helveticus R0052 and Bifidobacterium longum R0175) in healthy human volunteers. Gut Microbes 2:4, 256-261

Mitsunaga, J., Gragani, A., Ramos, M.L., et al, 2003. Rat an experimental model for burns: a systematic review. Acta Cir Bras;27(6), pp 23-417.

Olguin, F., Araya, M., Hirsch, S., Brunser, O., Ayala, V., Rivera, R., Gotteland, M., 2005. "Prebiotic ingestion does not improve gastrointestinal barrier function in burn patients". Burns. 31(4): 482-8.

Pavoni, V., Gianesello, L., Paparella, L., et al, 2010. Outcome predictors and quality of life of severe burn patients admitted to intensive care unit. Scandinavian Journal of Trauma, Resuscitation and Emergency Medicine, 18:24

Pereira, G., Miguel, M., Ramos, C., Schwan, R., 2012. Microbiological and physicochemical characterization of small-scale cocoa fermentations and screening of yeast and bacteria strains for the development of a defined starter culture. Applied and Environmental Microbiology, 78, pp. 5395-5405

Rao, A., Bested, A., Beaulne, T., et al, 2009.A randomized, double-blind, placebo-controlled pilot study of a probiotic in emotional symptoms of chronic fatigue syndrome.Gut Pathogens, 1:6

Saputro et al, 2012, Five Years Retrospective Study of Burns in Dr. Soetomo General Hospital Surabaya, PIT PERAPI Medan.

Tahir, S.M.,Makhdoom, A.,Awan, S., Ali, S. A., 2014. Role of Probiotics in the Management of Burns Patients. World Journal of Medical Sciences 11 (3): 417-421

Vyas, U. and Ranganathan, N., 2012. Probiotics, Prebiotics, and Synbiotics: Gut and Beyond.Gastroenterology Research and Practice Volume 16

Wadher K.J., Mahore, J.G and Umekar, M.J, 2010. Probiotics: Living Medicines in Health Maintenance and Disease Prevention. International Journal of Pharma and Bio Sciences, Vol.1/Issue-3 